\title{
Soil surface roughness change and its effect on runoff and erosion on the Loess Plateau of China
}

\author{
LongShan ZHAO, XinLan LIANG, FaQi WU* \\ College of Natural Resources and Environment, Northwest A\&F University, Yangling 712100, China
}

\begin{abstract}
As an important parameter in the soil erosion model, soil surface roughness (SSR) is used to quantitatively describe the micro-relief on agricultural land. SSR has been extensively studied both experimentally and theoretically; however, no studies have focused on understanding SSR on the Loess Plateau of China. This study investigated changes in SSR for three different tillage practices on the Loess Plateau of China and the effects of SSR on runoff and erosion yield during simulated rainfall. The tillage practices used were zero tillage (ZT), shallow hoeing (SH) and contour ploughing (CP). Two rainfall intensities were applied, and three stages of water erosion processes (splash erosion (I), sheet erosion (II) and rill erosion (III)) were analyzed for each rainfall intensity. The chain method was used to measure changes in SSR both initially and after each stage of rainfall. A splash board was used to measure the splash erosion at stage I. Runoff and sediment data were collected continuously at 2-min intervals during rainfall erosion stages II and III. We found that SSR of the tilled surfaces ranged from $1.0 \%$ to 21.9\% under the three tillage practices, and the order of the initial SSR for the three treatments was $\mathrm{ZT}<\mathrm{SH}<\mathrm{CP}$. For the ZT treatment, SSR increased slightly from stage I to III, whereas for the SH and CP treatments, SSR decreased by $44.5 \%$ and $61.5 \%$ after the three water erosion stages, respectively, and the greatest reduction in SSR occurred in stage I. Regression analysis showed that the changes in SSR with increasing cumulative rainfall could be described by a power function $\left(R^{2}>0.49\right)$ for the $\mathrm{ZT}, \mathrm{SH}$ and $\mathrm{CP}$ treatments. The runoff initiation time was longer in the $\mathrm{SH}$ and $\mathrm{CP}$ treatments than in the $\mathrm{ZT}$ treatment. There were no significant differences in the total runoff yields among the $\mathrm{ZT}, \mathrm{SH}$ and $\mathrm{CP}$ treatments. Sediment loss was significantly smaller $(P<0.05)$ in the $\mathrm{SH}$ and $\mathrm{CP}$ treatments than in the ZT treatment.
\end{abstract}

Keywords: tillage practice; soil surface roughness; overland flow; water erosion; Loess Plateau

Citation: LongShan ZHAO, XinLan LIANG, FaQi WU. 2014. Soil surface roughness change and its effect on runoff and erosion on the Loess Plateau of China. Journal of Arid Land, 6(4): 400-409. doi: 10.1007/s40333-013-0246-z

Soil surface roughness (SSR), which describes the micro-variation in soil elevations across a field resulting primarily from tillage practices and soil erosion, is one of the major factors in wind and water erosion (Freebairn et al., 1989; García Moreno et al., 2007). Due to its effects on surface storage capacity, infiltration rate, surface runoff and erosion processes (Helming et al., 1998; Römkens et al., 2001), SSR functions as an important parameter in many soil erosion or erosion prediction models (Kamphorst et al., 2000; Planchon et al., 2000; Planchon and Darboux, 2001). Previous studies have shown that different tillage prac- tices (Römkens and Wang, 1986; Guzha, 2004), cover crops (Lin and Richards, 2007), soil types (García Moreno et al., 2008) and water erosion processes (Dexter, 1977; Planchon et al., 2000) can cause variations in SSR.

In the past few decades, studies on SSR have progressed from simply quantifying and calculating SSR to determining the effects of SSR on soil erosion (Allmaras et al., 1966; Linden and Van Doren, 1986; Takken et al., 2001; Huang and Lee, 2009). Some researchers suggested that SSR can significantly weaken rainfall erosion force and extend runoff initiation time

"Corresponding author: FaQi WU (E-mail: wufaqi@263.net)

Received 2013-05-01; revised 2013-07-22; accepted 2013-08-11

(c) Xinjiang Institute of Ecology and Geography, Chinese Academy of Sciences, Science Press and Springer-Verlag Berlin Heidelberg 2014 
due to raised soil surfaces, runoff resistance and increased depression storage (Darboux et al., 2001; Takken et al., 2001; Rai et al., 2010). It has also been suggested that compared to a smooth slope, a rougher slope can significantly reduce soil erosion yield. Other researchers believed that the effects of SSR on soil erosion are limited due to the change in SSR itself during rainfall (Helming et al., 1998; Góvers et al., 2000). Gómez and Nearing (2005) reported that there were only slight differences in the total runoff yield and erosion yield between a smooth slope and a rougher slope. Regarding this observation, several scholars suggested that tillage reallocates the spatial distribution of the SSR characteristics, having an effect on the flow direction and flow concentration patterns on the sloping surface (Abrahams and Parsons, 1990; Takken et al., 2001). These changes could result in more concentrated runoff confluence on the sloping surface (Römkens et al., 2001) and intensified water erosion (Helming and Prasad, 2001), indicating that while SSR clearly has the capacity to weaken water erosion, it also has the potential to intensify it.

The Loess Plateau of China is an area where soil erosion leads to considerable problems (Sun et al., 2013). The annual sediment flow into the Yellow River is approximately 16 billion tons, with approximately $50 \%$ to $70 \%$ coming from the sloping land of the Loess Plateau (Tang, 2004). According to the most recent data, sloping land on the Loess Plateau covers an area of $6.75 \times 10^{4} \mathrm{~km}^{2}$, accounting for $43 \%$ of the arable land in this region (Xie, 2005). Currently, zero tillage, shallow hoeing and contour ploughing are the common tillage practices used for agricultural production in this region. In many parts of the world, SSR has been extensively investigated both experimentally and theoretically (Zobeck and Onstad, 1987; Rai et al., 2010); however, no studies have investigated SSR on the Loess Plateau of China.

The objectives of this experiment were (1) to study the changes in SSR for zero tillage, shallow hoeing and contour ploughing during rainfall and (2) to ana- lyze the impacts of SSR on the runoff and erosion processes.

\section{Material and methods}

\subsection{Study area and soil sampling}

Soil samples were collected in Yangling county, Shaanxi province, China ( $\left.34^{\circ} 17^{\prime} 56^{\prime \prime} \mathrm{N}, 108^{\circ} 04^{\prime} 07^{\prime \prime} \mathrm{E}\right)$. This area is located on the southern margin of the Loess Plateau. Yangling county has a temperate, semi-humid continental monsoon climate with an annual mean temperature of $13.0^{\circ} \mathrm{C}$. The mean annual precipitation and potential evaporation are $637 \mathrm{~mm}$ and 1,400 mm, respectively. Rainfall distribution is not uniform throughout the year, particularly in the summer when sudden storms are common. The winter wheat/summer maize rotation represents the main cropping system in this area.

Soil samples (approximately 6,000 kg) were collected at $0-20 \mathrm{~cm}$ depths on the sloping land with a gradient of $10^{\circ}$. The land had been continuously cultivated for more than ten years. The soil in this area is a manured sandy clay loam, whose major physical-chemical properties are shown in Table 1.

\subsection{Methods}

\subsubsection{Soil preparation in boxes}

The soil sample was passed through a 5-mm sieve to ensure homogeneity. Then, three soil boxes $(1 \mathrm{~m}$ in width, $0.5 \mathrm{~m}$ in depth and $2 \mathrm{~m}$ in length at a $10^{\circ}$ incline) were filled with the sieved soil in successive layers of 5.5-cm thickness, with a total of eight layers per box. The bulk density of each soil layer was 1.20 to $1.30 \mathrm{~g} / \mathrm{cm}^{3}$. Finally, the soil surfaces in the boxes were paralleled to the outlet of the box.

Additionally, SSR was simulated inside the boxes with a hoe. The tillage practices included zero tillage (ZT), shallow hoeing (SH) and contour ploughing (CP), which are common tillage practices used on the Loess Plateau of China. Photographs of three boxes with different types of SSR are shown in Fig. 1.

Table 1 Physical-chemical properties of the experimental soil samples at 0-20 cm depth

\begin{tabular}{|c|c|c|c|c|c|c|c|c|c|}
\hline $\begin{array}{c}\text { Organic } \\
\text { matter }\end{array}$ & $\begin{array}{c}\text { Total } \\
\mathrm{N}\end{array}$ & $\begin{array}{c}\text { Total } \\
\mathrm{P}\end{array}$ & CEC & \multicolumn{6}{|c|}{ Soil particle size distribution } \\
\hline & (g/kg) & & $(\mathrm{cmol} / \mathrm{kg})$ & $<0.001 \mathrm{~mm}$ & $0.001-0.005 \mathrm{~mm}$ & $0.005-0.01 \mathrm{~mm}$ & $0.01-0.05 \mathrm{~mm}$ & $0.05-0.25 \mathrm{~mm}$ & $0.25-2.00 \mathrm{~mm}$ \\
\hline 16.66 & 0.91 & 0.50 & 18.47 & $6.28 \%$ & $12.89 \%$ & $6.88 \%$ & $41.13 \%$ & $2.70 \%$ & $0.12 \%$ \\
\hline
\end{tabular}




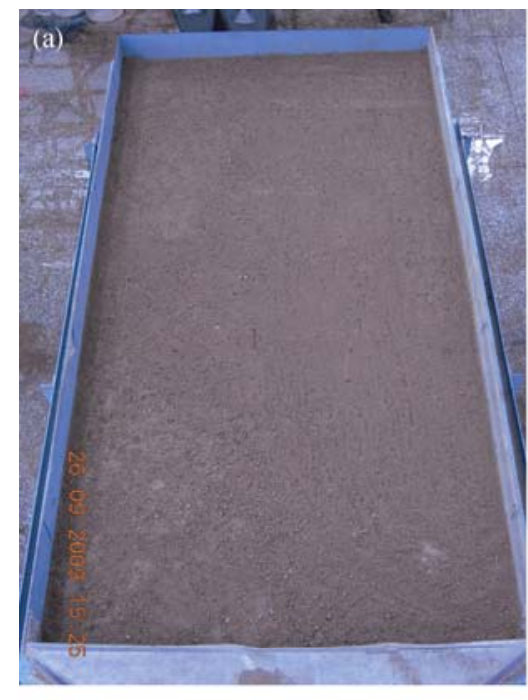

Zero tillage (ZT)

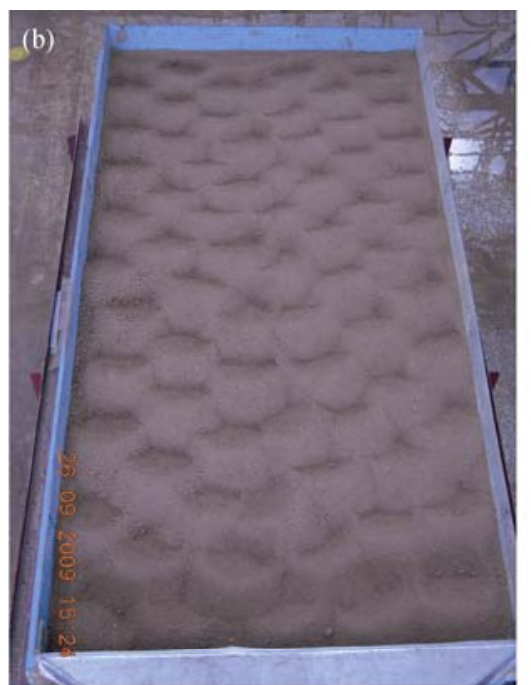

Shallow hoeing $(\mathrm{SH})$

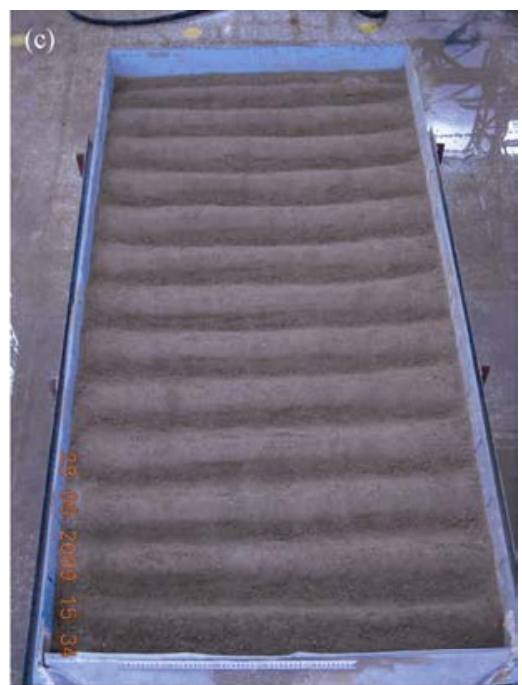

Contour ploughing $(\mathrm{CP})$

Fig. 1 Photographs of three boxes with different soil surface roughness (SSR)

\subsubsection{Rainfall application}

The rainfall application was conducted in the State Key Laboratory of Dryland Agriculture and Soil Erosion on the Loess Plateau in Yangling, China. A rainfall simulator system with a side-sprinkle precipitation set-up system was used to apply rainfall. The nozzles were mounted at a position $16 \mathrm{~m}$ above the ground. The simulator can adjust the rainfall intensity within the range of $40-260 \mathrm{~mm} / \mathrm{h}$ via nozzle size and water pressure. The simulated rainfall has uniformity greater than $80 \%$, and the raindrop distribution and size is similar to that of natural rainfall. In this study, the designated rainfall intensities were 60 and $120 \mathrm{~mm} / \mathrm{h}$. Before rainfall application, eight gauges were placed throughout the rainfall area to calibrate rainfall intensity.

To achieve the objective of this study, we designed a discontinuous rainfall experiment and measured changes in SSR and SSR's effects on runoff and erosion. There was an interval of 5-10 min between each stage of rainfall, in which SSR was measured. The reason for using short intervals was to eliminate the possible influence of the formation of a crust on the next stage of rainfall.

Specifically, the first stage lasted from the initiation of the rainfall to the point when runoff appeared on the soil surface and began flowing out of the box outlet; once the SSR measurement was taken after the first stage, the second stage of rainfall began and lasted to the point when the extensive runoff concentration process appeared and primary rill erosion was generated on the soil surface. For the final stage, rainfall application lasted for 60 and $30 \mathrm{~min}$ when rainfall intensities were 60 and $120 \mathrm{~mm} / \mathrm{h}$, respectively; the aim was to maintain similar amounts of rainfall for the different rainfall intensities applied in this stage. Considering that the dominant erosion processes occurred on the soil surface during rainfall, stages I, II and III corresponded to splash erosion, sheet erosion and rill erosion, respectively.

At stage I, a splash board was used to collect soil samples detached from the surface due to raindrop impact. Runoff samples were collected at 2-min intervals during stages II and III. The rainfall duration of stages I, II and III is shown in Table 2.

\subsubsection{Measurement of soil surface roughness}

In this study, SSR was measured using the chain method (Saleh, 1993). According to a review by Werrer and Andreas (2005), the chain method is the simplest and most convenient index of SSR. This method is theoretically based on the fact that horizontal length decreases as SSR increases when a chain $L_{1}$ of a given length is laid on the surface. Therefore, SSR could be measured by calculating decrements in the chain length using the equation below:

$$
S S R=\left(1-\frac{L_{2}}{L_{1}}\right) \times 100 .
$$

Where $L_{1}$ and $L_{2}$ represent the actual length and horizontal length when the chain is laid on the surface, respectively. 
Table 2 Rainfall duration of different stages under different tillage practices

\begin{tabular}{|c|c|c|c|c|}
\hline \multirow{2}{*}{$\begin{array}{l}\text { Rainfall intensity } \\
(\mathrm{mm} / \mathrm{h})\end{array}$} & \multirow{2}{*}{ Tillage practice } & \multicolumn{3}{|c|}{ Duration of rainfall simulation (min) } \\
\hline & & Splash erosion (I) & Sheet erosion (II) & Rill erosion (III) \\
\hline \multirow{3}{*}{60} & Zero tillage (ZT) & $8.62 \pm 2.07$ & $5.54 \pm 1.44$ & 60.00 \\
\hline & Shallow hoeing $(\mathrm{SH})$ & $9.75 \pm 0.62$ & $9.99 \pm 0.48$ & 60.00 \\
\hline & Contour ploughing (CP) & $21.15 \pm 3.98$ & $16.27 \pm 2.79$ & 60.00 \\
\hline \multirow{3}{*}{120} & Zero tillage (ZT) & $2.89 \pm 0.25$ & $5.27 \pm 1.68$ & 30.00 \\
\hline & Shallow hoeing (SH) & $3.88 \pm 0.45$ & $7.14 \pm 2.31$ & 30.00 \\
\hline & Contour ploughing (CP) & $7.68 \pm 1.79$ & $9.98 \pm 4.01$ & 30.00 \\
\hline
\end{tabular}

Note: Numbers are mean \pm SD. ${ }^{\text {a }}$ Standard deviations equal to zero due to the constant values of the rainfall duration of stage III.

\subsection{Data analysis}

Each treatment was replicated 3 times. After the experiment, the runoff coefficient, splash erosion rate, runoff erosion rate, total runoff yield and erosion yield were calculated using the runoff and sediment samples collected in the rainfall process. SSR was calculated using Eq. 1. Statistical analysis was carried out using DPS 7.05 software and the least significant difference (LSD) was used to test significant differences among the total runoff coefficients and erosion yields.

\section{Results and discussion}

\subsection{Change of soil surface roughness}

Figure 2 presented the original SSR for the three tillage practices and their changes during rainfall.

The initial SSR ranged from $1.0 \%$ to $1.5 \%$ in the ZT treatment, from $5.7 \%$ to $8.2 \%$ in the $\mathrm{SH}$ treatment and from $8.9 \%$ to $21.9 \%$ in the CP treatment. After the three stages of rainfall, the values of SSR had significantly decreased in the SH and CP treatments compared with the original SSR. On the contrary, for the ZT treatment, SSR gradually increased $(P<0.01)$ as rainfall increased (Table 3 ). These results are in general agreement with the assumption presented by Huang and Bradford (1992) and Magunda et al. (1997) that rainfall can produce changes in SSR, but whether the changes decrease or increase is largely dependent on the original condition of the soil surface.

The rate of change in SSR varied with the cumulative rainfall. For the $\mathrm{SH}$ and $\mathrm{CP}$ treatments, the greatest reduction in SSR occurred during stage I. Particularly, under a rainfall intensity of $60 \mathrm{~mm} / \mathrm{h}$, SSR in the $\mathrm{SH}$ treatment decreased from the initial SSR by $23 \%$, on average, after receiving $9.75 \mathrm{~mm}$ of rainfall within 9.75 min; meanwhile, SSR in the CP treatment decreased by $37 \%$ after receiving $21.15 \mathrm{~mm}$ of rainfall within $21.15 \mathrm{~min}$. When rainfall intensity was increased to $120 \mathrm{~mm} / \mathrm{h}$, SSR values for the SH and CP treatments decreased by $23 \%$ and $38 \%$, respectively. Accordingly, the rainfall amounts applied were 7.76 and $15.36 \mathrm{~mm}$ within 3.88 and $7.65 \mathrm{~min}$, respectively. During the last two stages of rainfall, however, the
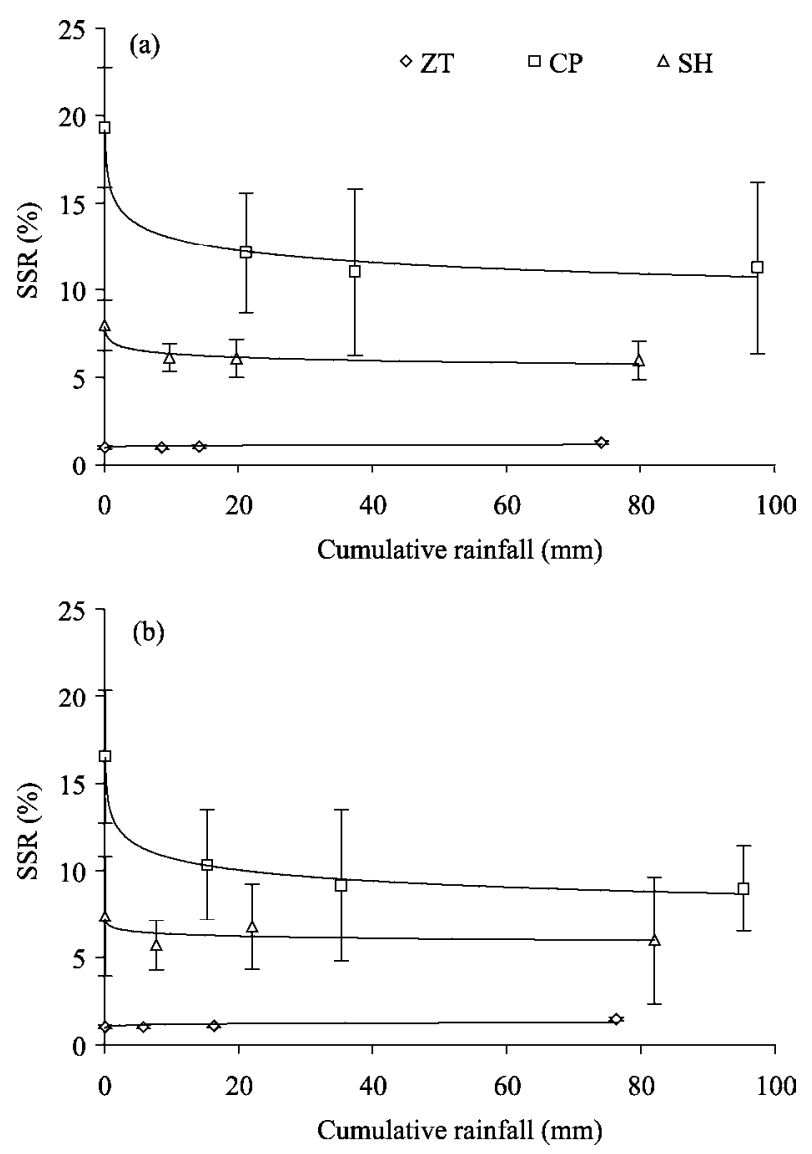

Fig. 2 Changes in soil surface roughness (SSR) with cumulative rainfall for each rough slope. (a), $60 \mathrm{~mm} / \mathrm{h}$; (b), $120 \mathrm{~mm} / \mathrm{h}$. 
Table 3 Relation of soil surface roughness (SSR) to rainfall amount under different rainfall intensities

\begin{tabular}{|c|c|c|c|c|c|c|c|}
\hline \multirow{3}{*}{$\begin{array}{l}\text { Tillage } \\
\text { practice }\end{array}$} & \multicolumn{6}{|c|}{ Rainfall intensity } & \multirow{3}{*}{ Model } \\
\hline & \multicolumn{3}{|c|}{$60 \mathrm{~mm} / \mathrm{h}$} & \multicolumn{3}{|c|}{$120 \mathrm{~mm} / \mathrm{h}$} & \\
\hline & $\mathrm{a}$ & $\mathrm{b}$ & $R^{2}$ & $\mathrm{a}$ & $\mathrm{b}$ & $R^{2}$ & \\
\hline $\mathrm{ZT}$ & 0.989 & 0.003 & $0.988^{* *}$ & 0.986 & 0.005 & $0.996^{* *}$ & $y=\mathrm{a} \times \exp (\mathrm{b} x)$ \\
\hline $\mathrm{SH}$ & 7.056 & -0.046 & $0.950^{* *}$ & 6.758 & -0.028 & $0.496^{*}$ & 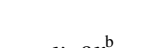 \\
\hline $\mathrm{CP}$ & 15.780 & -0.084 & $0.974^{* *}$ & 13.285 & -0.093 & $0.989^{* *}$ & $y=a x$ \\
\hline
\end{tabular}

Note: $\mathrm{a}$ and $\mathrm{b}$ are the best fitted parameters in regression models for SSR and rainfall amount. $y$ is SSR and $x$ is cumulative rainfall (mm); $R^{2}$ is the coefficient of determination. ${ }^{* *}, P<0.01 ;{ }^{*}, P=0.26$.

rates of change in SSR were significantly reduced compared with the reduction observed during stage I. These results suggested that earlier rain had a greater effect on SSR. The subsequent rainfall also caused a decrease in SSR, but the rate may have been reduced. Our results confirmed those previously reported by De Oro and Buschiazzo (2011), which indicated degradation rates in SSR of up to 53\% after $7 \mathrm{~mm}$ of rainfall within $10 \mathrm{~min}$, with even greater rates after $28 \mathrm{~mm}$ of subsequent rainfall within $40 \mathrm{~min}$. The rapid decrease in SSR during stage I of rainfall may be attributed primarily to the consolidation of the loosely tilled soil upon drying, resulting from a decrease in the negative pore pressures (Allmaras et al., 1966; Sun et al., 2009), and the breakdown and sloughing of soil clod upon wetting during rainstorms (Römkens and Wang, 1987). Furthermore, the reductions in SSR changes with increases in cumulative rainfall could be attributed to the hydrological response of surface microrelief to rainfall-runoff processes. On the one hand, the height of surface microrelief decreased as the sediment was transported by runoff, and as a result, SSR was reduced (Dexter, 1977; Römkens and Wang, 1986; De Oro and Buschiazzo, 2011). On the other hand, rill networks were generated on the surface due to concentrated flow, causing SSR to increase (Darboux et al., 2001; Gómez et al., 2003). Consequently, SSR as a whole exhibited a slight change, even though a significant change in spatial structure of microrelief was commonly observed after a long-term rainfall. In addition, the sealing and crust formed on the surface also had important effects on the changes in SSR, due to their significant effects on soil erodibility (Moore and Singer, 1990; Fohrer et al., 1999). For the ZT treatment, SSR increased by $4 \%$ and $21 \%$ after stages II and III, respectively, when rainfall intensity was 60 $\mathrm{mm} / \mathrm{h}$, and by $7 \%$ and $45 \%$, respectively, when rain- fall intensity was $120 \mathrm{~mm} / \mathrm{h}$. Certainly, the increase in SSR for the ZT treatment was related to the shear force of overland flow. The surface contained many discrete crescent-shaped pits following rainfall.

To analyze the relationship between SSR and rainfall amount under the different rainfall intensities, the regression equations for each treatment were fitted based on the method of least squares (Table 3). For the $\mathrm{ZT}$ treatment, the equation was exponential $(P<0.01)$, and the determination coefficients were 0.988 and 0.996 for the rainfall intensities of 60 and $120 \mathrm{~mm} / \mathrm{h}$, respectively. By contrast, the changes in SSR for the SH and CP treatments followed a power function. With the exception of the SH treatment at the rainfall intensity of $120 \mathrm{~mm} / \mathrm{h}$, for all the other treatments, this power function reflected more than $95 \%$ of the changes in SSR due to rainfall $(P<0.01)$. The models proposed by Römkens and Wang (1987) and Zobeck and Onstad (1987) successively predicted changes in SSR due to rainfall (Table 4). In particular, as described in their discussions, Model 2 (Römkens and Wang, 1987) and Model 3 (Zobeck and Onstad, 1987) could explain more than $97 \%$ and $76 \%$, respectively, of the changes in SSR by rainfall. These three models, however, were not used to predict changes in SSR under our experimental conditions. The problem with using such models stems from the initial SSR, as the tillage practice is the greatest factor influencing SSR in the agricultural field (Römkens and Wang, 1986).

\subsection{Surface runoff}

The effects of SSR on the surface runoff were explained by analyzing differences in the surface runoff coefficients and total runoff yields between the different tillage practices. Table 5 presents the surface runoff initiation times at stages I, II and III, as well as the surface runoff coefficients, total runoff coefficients 
Table 4 Models to predict soil surface roughness after rainfall

\begin{tabular}{cl}
\hline No. & \multicolumn{1}{c}{ Model } \\
\hline 1 & $R R=1 /(\mathrm{a}+\mathrm{b} x)$, where $\mathrm{x}$ is the cumulative rainfall and a and $\mathrm{b}$ are constants. \\
2 & $\begin{array}{l}R R=\left(C_{1}+C_{2}\right) \times \exp \left(-C_{3} r\right) \text {, where } C_{1}, C_{2} \text { and } C_{3} \text { are regression coefficients, and } r \text { is cumulative } \\
\text { rainfall. } \\
R R=R R_{0} \times 0.89 \times \exp (-0.026 P), \text { where } R R_{0} \text { is the roughness before rainfall and } P \text { is the intervening } \\
\text { rainfall amount. }\end{array}$ \\
\hline
\end{tabular}

Table 5 Statistics of mean runoff time, runoff coefficient and accumulated runoff yield

\begin{tabular}{|c|c|c|c|c|c|c|c|c|c|}
\hline \multirow{2}{*}{$\begin{array}{c}\text { Rainfall } \\
\text { intensity } \\
(\mathrm{mm} / \mathrm{h})\end{array}$} & \multirow{2}{*}{$\begin{array}{l}\text { Tillage } \\
\text { practice }\end{array}$} & \multicolumn{3}{|c|}{ Runoff initiation time (min) } & \multicolumn{3}{|c|}{ Runoff coefficient (\%) } & \multirow{2}{*}{$\begin{array}{c}\text { Total runoff } \\
\text { coefficient } \\
\text { (\%) }\end{array}$} & \multirow{2}{*}{$\begin{array}{l}\text { Total runoff yield } \\
\left(\mathrm{mm} / \mathrm{m}^{2}\right)\end{array}$} \\
\hline & & I & II & III & I & II & III & & \\
\hline \multirow{3}{*}{60} & $\mathrm{ZT}$ & $8.62 \pm 2.07$ & $2.89 \pm 0.59$ & $1.72 \pm 0.42$ & 0 & $31.74 \pm 4.34$ & $50.79 \pm 2.94$ & $49.12^{\mathrm{a}}$ & $16.08 \pm 0.84^{\mathrm{a}}$ \\
\hline & $\mathrm{SH}$ & $9.75 \pm 0.62$ & $4.55 \pm 0.50$ & $2.99 \pm 0.20$ & 0 & $8.54 \pm 3.69$ & $38.67 \pm 8.32$ & $35.14^{b}$ & $11.94 \pm 2.64^{\mathrm{a}}$ \\
\hline & $\mathrm{CP}$ & $21.15 \pm 3.98$ & $9.83 \pm 2.47$ & $7.07 \pm 2.27$ & 0 & $4.79 \pm 2.18$ & $41.48 \pm 4.60$ & $33.52^{\mathrm{b}}$ & $12.81 \pm 1.28^{\mathrm{a}}$ \\
\hline \multirow{3}{*}{120} & $\mathrm{ZT}$ & $2.89 \pm 0.25$ & $0.89 \pm 0.12$ & $0.64 \pm 0.14$ & 0 & $75.29 \pm 10.70$ & $81.49 \pm 9.60$ & $80.62^{\mathrm{a}}$ & $28.56 \pm 4.72^{\mathrm{a}}$ \\
\hline & $\mathrm{SH}$ & $3.88 \pm 0.45$ & $1.35 \pm 0.20$ & $1.23 \pm 0.36$ & 0 & $54.21 \pm 5.85$ & $75.41 \pm 9.77$ & $71.86^{\mathrm{ab}}$ & $26.50 \pm 2.18^{\mathrm{a}}$ \\
\hline & $\mathrm{CP}$ & $7.68 \pm 1.79$ & $3.73 \pm 1.03$ & $1.88 \pm 0.31$ & 0 & $30.51 \pm 1.52$ & $64.49 \pm 4.33$ & $56.05^{b}$ & $22.45 \pm 2.63^{\mathrm{a}}$ \\
\hline
\end{tabular}

Note: I, splash erosion; II, sheet erosion; III, rill erosion. Numbers are mean \pm SD. Values followed by the same letter are not significantly different for the least significant difference test at $P<0.05$.
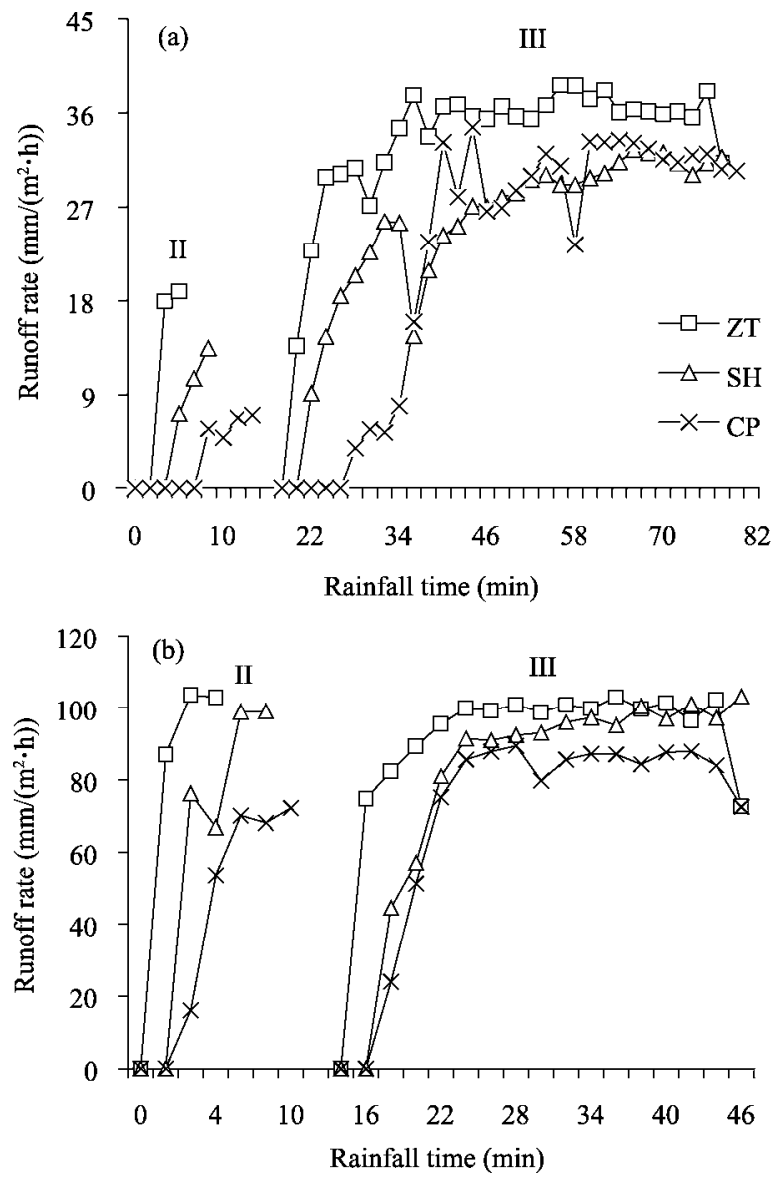

Fig. 3 The changes in runoff rates on the sloping surface with rainfall time under different rainfall intensities and roughness. (a), rainfall intensity of $60 \mathrm{~mm} / \mathrm{h}$; (b), rainfall intensity of $120 \mathrm{~mm} / \mathrm{h}$. and total runoff yields. Figure 3 shows the runoff rates for the $\mathrm{ZT}, \mathrm{SH}$ and $\mathrm{CP}$ treatments during rainfall, when the rainfall intensities were respectively 60 and $120 \mathrm{~mm} / \mathrm{h}$ (average of three replications).

For rainfall intensities of 60 and $120 \mathrm{~mm} / \mathrm{h}$, there was a delay in the surface runoff initiation times in the $\mathrm{SH}$ and $\mathrm{CP}$ treatments compared with the ZT treatment (Table 5; Fig. 3). This result is in general agreement with the results previously reported by Helming et al. (1998) and Góvers et al. (2000). The rougher the soil surface is, the longer the time of runoff initiation. This is because the surface storage capacity and infiltration rate are highest at the beginning of the rainfall event (Darboux et al., 2001, 2002); however, the runoff delay effect of SSR was significantly reduced between stages I and III due to the changes in SSR. In addition, the seal and crust formation on the soil surface was also an important factor that decreased SSR's effect on runoff.

There were significant differences in the runoff coefficients between the different stages of rainfall for the three tillage practices (Table 5). For all treatments, the runoff coefficients were zero at stage I because the rainfall was stopped immediately when runoff was generated on the surface. At stage II, the runoff coefficient in the ZT treatment was $31.74 \%$, which was three times greater than the coefficients in the $\mathrm{SH}$ and CP treatments (8.54\% and 4.79\%, respectively) during 
the rainfall intensity of $60 \mathrm{~mm} / \mathrm{h}$. During the rainfall intensity of $120 \mathrm{~mm} / \mathrm{h}$, the runoff coefficients were 75.29\%, $54.21 \%$ and $30.51 \%$ for the ZT, SH and CP treatments, respectively, at stage II. The runoff coefficients were lower at stage II than at stage III for all of the treatments. The lower runoff coefficients can be attributed to the high capacity for temporary storage in depressions prior to the connection of flowpaths and the generation of rill networks on the soil surface (Darboux and Huang, 2005). Furthermore, the drop in infiltration capacity of soil may be another important factor responsible for the increases in the runoff coefficients from stage II to III (Magunda et al., 1997).

During the rainfall intensity of $60 \mathrm{~mm} / \mathrm{h}$, significant differences $(P<0.05)$ in the total runoff coefficients were observed between the $\mathrm{ZT}$ and $\mathrm{SH}$ treatments and between the ZT and CP treatments; however, during the $120 \mathrm{~mm} / \mathrm{h}$ rainfall intensity, a significant difference $(P<0.05)$ was found only between the ZT and CP treatments. As such, these results indicated that SSR had a significant effect on the total runoff coefficient and that the effect of SSR on the total runoff coefficient declined as rainfall intensity increased. These observations contradict the results of Helming et al. (1998), who observed that rainfall intensity had only a small effect on the runoff coefficient under an experimental slope (17\%) similar to our $10^{\circ}$ slope. We hypothesize that this contradiction in results is mainly due to the difference in rainfall procedures used. In our experiment, rainfall was applied to fresh soil for each rainfall intensity, whereas in the experiment by Helming et al. (1998), all rainfall intensities were successively applied to one soil bed, so the effects of initial and early SSR on the runoff coefficient were not observed.
For the total runoff, there were no significant differences $(P>0.05)$ between the $\mathrm{ZT}, \mathrm{SH}$ and $\mathrm{CP}$ treatments at rainfall intensities of 60 and $120 \mathrm{~mm} / \mathrm{h}$. This result was similar to those reported by Gómez and Nearing (2005) and Ndiaye et al. (2005). For all treatments, the runoff rates tended to stabilize at approximately $60 \mathrm{~min}$ for the rainfall intensity of 60 $\mathrm{mm} / \mathrm{h}$ and at $30 \mathrm{~min}$ for the rainfall intensity of 120 $\mathrm{mm} / \mathrm{h}$ (Fig. 3). This result indicated that the evolution of SSR and development of flowpath connectivity were more or less completed during the stage III rainfall. The differences in the steady-state runoff rates between the different SSR treatments were gradually reduced. Darboux and Huang (2005) suggested that the actual reason for the effects of SSR on runoff was the depression storage delay in the time of runoff initiation at the beginning of the rain event, before the entire surface was contributing to runoff. Once runoff reached an apparent steady state, surfaces with initial depressions produced $10 \%$ greater water flux than the initially smooth surfaces, so no significant differences were measured between the rough and smooth surfaces.

\subsection{Sediment}

Table 6 shows the splash rates, runoff erosion rates and total sediments under the different SSR treatments at stages I, II and III. The mean splash rates, runoff erosion rates and the total sediments in the SH and CP treatments were significantly lower than in the ZT treatment under rainfall intensities of both 60 and 120 $\mathrm{mm} / \mathrm{h}$. Statistical results showed that the differences in total sediment were significant between the $\mathrm{ZT}$ and SH treatments and the ZT and CP treatments. These results indicate that SSR could clearly reduce soil loss

Table 6 Erosion stages and accumulated erosion yields under different rainfall intensities and tillage practices.

\begin{tabular}{|c|c|c|c|c|c|}
\hline \multirow{2}{*}{$\begin{array}{c}\text { Rainfall } \\
\text { intensity } \\
(\mathrm{mm} / \mathrm{h})\end{array}$} & \multirow{2}{*}{$\begin{array}{l}\text { Tillage } \\
\text { practice }\end{array}$} & Stage I & Stage II & Stage III & \multirow[b]{2}{*}{ Total sediment $\left(\mathrm{kg} / \mathrm{m}^{2}\right)$} \\
\hline & & Splash rate $\left(\mathrm{kg} /\left(\mathrm{m}^{2} \cdot \mathrm{h}\right)\right)$ & $\begin{array}{l}\text { Runoff erosion rate } \\
\left(\mathrm{kg} /\left(\mathrm{m}^{2} \cdot \mathrm{h}\right)\right)\end{array}$ & $\begin{array}{c}\text { Runoff erosion rate } \\
\left(\mathrm{kg} /\left(\mathrm{m}^{2} \cdot \mathrm{h}\right)\right)\end{array}$ & \\
\hline \multirow{3}{*}{60} & $\mathrm{ZT}$ & $0.05 \pm 0.02$ & $1.28 \pm 1.11$ & $0.36 \pm 0.05$ & $0.38^{\mathrm{a}}$ \\
\hline & $\mathrm{SH}$ & $0.02 \pm 0.01$ & $0.18 \pm 0.14$ & $0.10 \pm 0.03$ & $0.11^{\mathrm{b}}$ \\
\hline & $\mathrm{CP}$ & $0.02 \pm 0.01$ & $0.05 \pm 0.02$ & $0.11 \pm 0.03$ & $0.10^{\mathrm{b}}$ \\
\hline \multirow{3}{*}{120} & ZT & $0.20 \pm 0.03$ & $3.11 \pm 0.83$ & $1.05 \pm 0.20$ & $0.71^{\mathrm{a}}$ \\
\hline & $\mathrm{SH}$ & $0.08 \pm 0.01$ & $1.28 \pm 0.45$ & $0.78 \pm 0.04$ & $0.49^{\mathrm{b}}$ \\
\hline & $\mathrm{CP}$ & $0.05 \pm 0.01$ & $2.53 \pm 2.43$ & $0.62 \pm 0.29$ & $0.43^{\mathrm{b}}$ \\
\hline
\end{tabular}

Note: Numbers are mean \pm SD. Values followed by the same letter are not significantly different for the least significant difference test at $P<0.05$. 
under our experimental conditions. The findings in this study are completely consistent with those findings reported by Römkens et al. (2001) and Gómez and Nearing (2005). The result discussed above (Section 2.2) showed that no significant differences in total runoff were found between the different surface treatments, while the differences in total sediment were significant between the $\mathrm{ZT}$ and $\mathrm{SH}$ treatments and the ZT and CP treatments. Helming et al. (1998) explained that SSR influences soil loss by affecting the spatial distribution of runoff. No significant difference in total sediment, however, was observed between the SH and CP treatments.

At stage I, the mean splash rate declined with increasing SSR (Table 6). Hairsine et al. (1992) explained that the ponded water in depressions can effectively prevent soil detachment caused by raindrop impact. Furthermore, the microrelief could also influence the detachment capacity of raindrops. On the one hand, the microrelief on the rough surface increased surface area, resulting in decreased raindrop impact as the raindrops were spread over a larger area (Góvers et al., 2000). On the other hand, the microrelief on the rough surface increased the local slope of the surface, resulting in a high anisotropy of splash droplets (De Lima, 1989).

The dynamic changes in runoff erosion rates under rainfall intensities of both 60 and $120 \mathrm{~mm} / \mathrm{h}$ are presented in Fig. 4. At the beginning of the rainfall, the runoff erosion rates increased sharply. After a moment, these rates began to decline gradually, reaching a stable state by the end of the rainfall. This process was in general agreement with the features described in the literature by Römkens et al. (2001); however, some obvious differences in the dynamic changes in runoff erosion rates between the different treatments can be found in Fig. 4. Firstly, at stages II and III, the runoff erosion rate curves for the ZT treatment were above the curves for the $\mathrm{SH}$ and $\mathrm{CP}$ treatments under the rainfall intensity of $60 \mathrm{~mm} / \mathrm{h}$; however, at the end of stage III, the runoff erosion rates had reached an equilibrium state when rainfall intensity was $120 \mathrm{~mm} / \mathrm{h}$. Secondly, fluctuation in the runoff erosion rate curve is generally considered to reflect rill or incision erosion. In our experiment, repeated fluctuations in the runoff erosion rate curves could be observed at stage III with $60 \mathrm{~mm} / \mathrm{h}$ rainfall intensity. These fluctuations suggested that rill or incision erosion was actively occurring during this period. Repeated fluctuations in the runoff erosion rate curves were not observed under the rainfall intensity of $120 \mathrm{~mm} / \mathrm{h}$, however, suggesting that surfaces with similar tillage practices responded differently to different rainfall intensities.
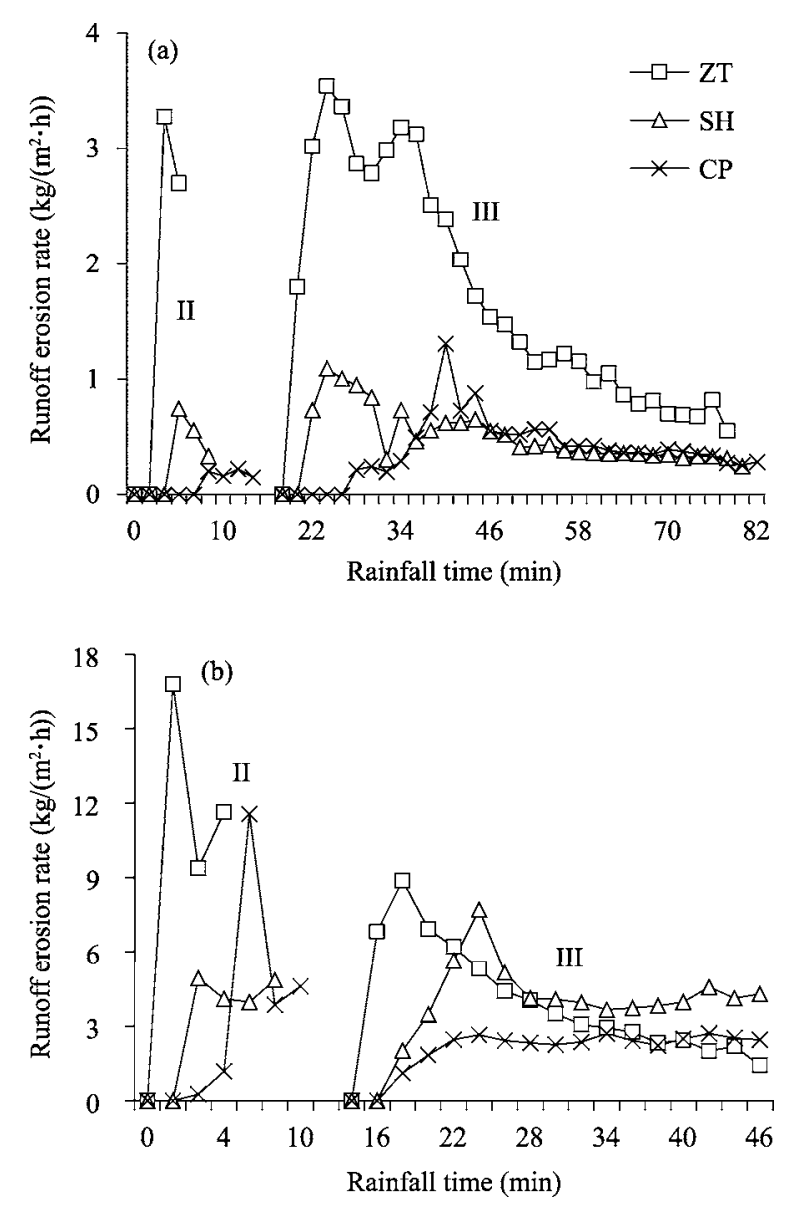

Fig. 4 The runoff erosion rate for each SSR treatment and rainfall. (a), rainfall intensity of $60 \mathrm{~mm} / \mathrm{h}$; (b), rainfall intensity of $120 \mathrm{~mm} / \mathrm{h}$.

Additionally, we hypothesized that depressions on the surface played a decisive role in reducing total sediments for the $\mathrm{SH}$ and $\mathrm{CP}$ treatments, as more sediments were deposited in these areas following rainfall. An experiment conducted by Gómez et al. (2003) showed that the depressions created during tillage were the areas where net deposition occurred during rainfall, as depressions acted as temporary puddles before the retained water overflowed and flowpath connectivity occurred across the surface (Darboux et al., 2001). 


\section{Conclusions}

The tillage practices studied in this experiment here were $\mathrm{ZT}, \mathrm{SH}$ and $\mathrm{CP}$, and the order of the initial SSR among the three treatments was $\mathrm{ZT}<\mathrm{SH}<\mathrm{CP}$. The results showed that the SSR in the SH and CP treatments significantly decreased as the cumulative rainfall amount increased. The changes in SSR with increasing cumulative rainfall can be described by a power function $\left(R^{2}>0.49\right)$. For the $\mathrm{SH}$ and $\mathrm{CP}$ treatments, the partially eroded sediments from relatively higher parts of the surface were deposited at the depressional area of the surface, resulting in a lower runoff erosion rate and total sediment compared with the ZT treatment. Meanwhile, the deposition increased the elevations of depressions and hence reduced the effective storage capacity of depressions. As a result, the effect of SSR on runoff disappeared gradually with increasing cumulative rainfall. It may be concluded that the effect of SSR on surface runoff was limited, while the effect of SSR on erosion was not due to the trapping effect of depressions on the eroded sediment. Therefore, to reduce both runoff and soil loss on the agricultural lands of the Loess Plateau, it is not enough to depend solely on the surface roughness. Other conservation measures are also needed.

\section{Acknowledgments}

This research was supported by the National Natural Science Foundation of China (41271288, 41371273). We thank researchers in the State Key Laboratory of Dryland Agriculture and Soil Erosion on the Loess Plateau for their valuable assistance. We also thank the editors and two anonymous reviewers for their constructive comments, which helped to improve the manuscript.

\section{References}

Abrahams A D, Parsons A J. 1990. Determining the mean depth of overland flow in field studies of flow hydraulics. Water Resources Research, 26(3): 501-503.

Allmaras R R, Burwell R E, Larson W E, et al. 1966. Total porosity and random roughness of the inter-row zone as influenced by tillage. USDA Conservation Research Report, No. 7: 1-14

Darboux F, Davy P, Gascuel-Odoux C, et al. 2001. Evolution of soil surface roughness and flow path connectivity in overland flow experiments. Catena, 46(2-3): 125-139.

Darboux F, Gascuel-Odoux C, Davy P. 2002. Effects of surface water storage by soil roughness on overland-flow generation. Earth Surface
Processes and Landforms, 27(3): 223-233.

Darboux F, Huang C H. 2005. Does soil surface roughness increase or decrease water and particle transfers?. Soil Science Society of America Journal, 69(3): 748-756.

De Lima J L M P. 1989. Raindrop splash anisotropy: slope, wind and overland flow veolocity effects. Soil Technology, 2(1): 71-78.

Dexter A R. 1977. Effect of rainfall on the surface micro-relief of tilled soil. Journal of Terramechanics, 14(1): 11-22.

De Oro L A, Buschiazzo D E. 2011. Degradation of the soil surface roughness by rainfall in two loess soils. Geoderma, 164(1-2): 46-53.

Fohrer N, Berkenhagen J, Hecker J M, et al. 1999. Changing soil and surface conditions during rainfall single rainstorm/subsequent rainstorms. Catena, 37(3-4): 355-375.

Freebairn D M, Gupta S C, Onstad C A, et al. 1989. Antecedent rainfall and tillage effects upon infiltration. Soil Science Society of America Journal, 53(4): 1183-1189.

García Moreno R, Díaz Álvarez M C, Saa Requejo A, et al. 2007. Multifractal analysis of soil surface roughness. Vadose Zone Journal, 7(2): 512-520.

García Moreno R, Díaz Álvareza M C, Tarquis Alonsob A, et al. 2008. Tillage and soil type effects on soil surface roughness at semiarid climatic conditions. Soil \& Tillage Research, 98(1): 35-44.

Gómez J A, Darboux F, Nearing M A. 2003. Development and evolution of rill networks under simulated rainfall. Water Resources Research, 39(6): 1148, doi: 10.1029/2002WR001437.

Gómez J A, Nearing M A. 2005. Runoff and sediment losses from rough and smooth soil surfaces in a laboratory experiment. Catena, 59(3): 253-266.

Góvers G, Takken I, Helming K. 2000. Soil roughness and overland flow. Agronomine, 20(2): 131-146.

Guzha A C. 2004. Effects of tillage on soil micro-relief, surface depression storage and soil water storage. Soil \& Tillage Research, 76(2): 105-114.

Hairsine P B, Moran C J, Rose C W. 1992. Recent developments regarding the influence of soil surface characteristics on overland flow and erosion. Soil Research, 30(3): 249-264.

Helming K, Römkens M J M, Prasad S N. 1998. Surface roughness related processes of runoff and soil loss: a flume study. Soil Science Society of America Journal, 62(1): 243-250.

Helming K, Prasad S N. 2001. Soil erosion under different rainfall intensities, surface roughness, and soil water regimes. Catena, 46(2-3): 103-123.

Huang C H, Bradford J M. 1992. Application of a laser scanner to quantify soil microrelief. Soil Science Society of America Journal, 56(1): 14-21.

Huang J K, Lee K T. 2009. Influences of spatially heterogeneous roughness on flow hydrographs. Advances in Water Resources, 32(11): 1580-1587.

Kamphorst E C, Jetten V, Guérif J, et al. 2000. Predicting depressional storage from soil surface roughness. Soil Science Society of America 
Journal, 64(5): 1749-1758.

Lin B B, Richards P L. 2007. Soil random roughness and depression storage on coffee farms of varying shade levels. Agricultural Water Management, 92(3): 194-204.

Linden D R, Van Doren D M. 1986. Parameters for characterizing tillage-induced soil surface roughness. Soil Science Society of America Journal, 50(6): 1560-1565.

Magunda M K, Larson W E, Linden D R, et al. 1997. Changes in microrelief and their effects on infiltration and erosion during simulated rainfall. Soil Technology, 10(1): 57-67.

Moore D C, Singer M J. 1990. Crust formation effects on soil erosion processes. Soil Science Society of America Journal, 54(4): 1117-1123.

Ndiaye B, Esteves M, Vandervaere J P, et al. 2005. Effect of rainfall and tillage direction on the evolution of surface crusts, soil hydraulic properties and runoff generation for a sandy loam soil. Journal of Hydrology, 307(1-4): 294-311.

Planchon O, Estevesb M, Silveraa N, et al. 2000. Raindrop erosion of tillage induced micro-relief: possible use of the diffusion equation. Soil \& Tillage Research, 56(3-4): 131-144.

Planchon O, Darboux F. 2001. A fast, simple and versatile algorithm to fill the depressions of digital elevation models. Catena, 46(2-3): 159-176.

Rai R K, Upadhyay A, Singh V P. 2010. Effect of variable roughness on runoff. Journal of Hydrology, 382(1-4):115-127.

Römkens M J M, Wang J Y. 1986. The effect of tillage on surface roughness. Transactions of the American Society of Agricultural
Engineers, 29: 429-433.

Römkens M J M, Wang J Y. 1987. Soil roughness changes from rainfall. Transactions of the American Society of Agricultural Engineers, 30(1): 101-107.

Römkens M J M, Helming K, Prasad S N. 2001. Soil erosion under different rainfall intensities, surface roughness, and soil water regimes. Catena, 46(2-3): 103-123.

Saleh A. 1993. Soil roughness measurement: chain method. Journal of Soil and Water Conservation, 48(6): 527-529.

Sun Y, Lin J, Lammers P S, et al. 2009. Predicting surface porosity using a fine-scale index of roughness in a cultivated field. Soil \& Tillage Research, 103(1): 57-64.

Sun W Y, Shao Q Q, Liu J Y. 2013. Soil erosion and its response to the changes of precipitation and vegetation cover on the Loess Plateau. Journal of Geographical Sciences, 23(6): 1091-1106.

Takken I, Govers G, Jetten V, et al. 2001. Effects of tillage on runoff and erosion patterns. Soil \& Tillage Research, 61(1-2): 55-60.

Tang K L. 2004. Soil and Water Conservation of China. Beijing: Science Press, 25-34.

Werrer J, Andreas K. 2005. Soil surface roughness measurement-methods, applicability, and surface representation. Catena, 64(2-3): 174-192.

Xie J Q. 2005. Sloping Fields of China. Beijing: China Land Press, 24-26.

Zobeck T M, Onstad C A. 1987. Tillage and rainfall effects on random roughness: a review. Soil \& Tillage Research, 9(1): 1-20. 